\title{
Work Life Balance among Women Police in Salem City, Tamil Nadu
}

\section{Bhuvaneswari, P. Thirumoorthi}

\begin{abstract}
A main societal norm is work. At times it may be challenging and it tries to prioritize over your welfare. The impact that work life balance has on many social harms has been increasing nowadays, some are reflected in certain forms like tardiness, lessening fertility rates, aged populations and declining supply of quality labour. Certainly, a work culture that demands round the clock, i.e. 24/7 availability becomes a very big victimization to the above said social issues. It is known that Police personnel's service and its effects on the family is a complex phenomenon. The function of women police is vague and workplace pressure is viewed as an unsuccessful factor, but a predictable part of police work. Police stress is influenced by a various workplace troubles like ethnic and gender partiality and lack of authority, work-load activities. Issues like family size, children's age, and uncertain working hours has caused dissatisfaction and are more expected to wield negative impacts in their family and in work, that has led to low level of satisfaction, and greater family-work conflict.

This research study is an attempt to spot out the effects of work-life balance and to explore the main factors which cause work-family challenges among different categories of women personnel in police department. By using convenient sampling technique, a sample of 50 respondents was collected. Structured questionnaire were used to collect primary data from the Police women. The secondary data was collected from various existing sources like website and reports. For statistical analysis, researcher used SPSS and Statistical tools like (i.e.) percentage analysis, ANOVA, Chi-square. The inferences of this study reveal that the age of respondents and their family factors have significant effects in ensuring work-life balance. Hence, the results suggest that supportive working conditions, employee wellness programme, and timely promotion and transfer policies can ensure work - life balance among the respondents.
\end{abstract}

Key words: Work-life balance, occupational stress, Familywork conflict, Women police.

\section{THEORITICAL FRAMEWORK}

The dynamics of the economic reforms gave a mount to the concept of work-life balance. Previously, workers grouped their life into two categories, i.e., 'in work' and 'outside of work'.

Job related work

was not carried at home and house-hold activities were not conducted at work. The laborers' point was to limit 'work' and expand 'life'. This has consumed the psyches of numerous laborers for a century or somewhere in the vicinity. Today, the situation has changed. Due to obscuring geological limits, individuals are working later into the day and still later till their endurance. Enhancements in innovation and late developments have additionally affected the socio-social setting by bringing multi-faceted ways of life in numerous Indian houses. Amongst all this,

Revised Manuscript Received on December 05, 2019.

* Correspondence Author

D. Bhuvaneswari*, Department of Management Studies, Periyar University, Salem, India. Email: bhuvi39.grt@gmail.com

Dr. P. Thirumoorthi, Department of Management Studies, Periyar University, Salem, India. Email: peeteem005@gmail.com the undeniable need for development in composite domains, for individuals as well as for firms has led to poor balance in the lives of the workforce. Thus, we are in a compulsion to come back to work-life integration.

\section{A. Concept of Work-Life Balance}

WLB doesn't mean an equal balance. On a daily basis, person's WLB might vary over time. The present right parity may not be tomorrow. The pure adjusts additionally contrast when one is singular and one gets married and when he/she have youngsters. Specifically, working women can't part her individual life and family life, as both of these are associated and requires a great deal of consideration. So, work-life balance is a notion that portrays the idyllic of splitting individual's time and energy between work and other vital phases of their life.

\section{B. WLB \& Women}

In recent decades, Women have entered the workforce in an extraordinary manner and enhanced their performance and earnings on par with men. There is still a myth, that as though it is the main job of men to be wage earners, and the foremost job of women to be homemakers and caretakers of children and the elderly. It is the epoch of women empowerment. In both developed and developing countries, the position of women in the society has an imperative contribution towards economic activity. In growing countries like India, the family income is said to be low and that can be enhanced by woman's work and through her earnings. Thus, when the married working woman enforced to combine her twin roles, i.e., personal life and work, she faces mental problems and complicatedness, and which in turn leads to a so called problem 'role conflict'. This is the most significant problem to the woman who strives to achieve a high position in her career and professions, since these roles are equally challenging and important. Roleconflict was sensed because the acuity of the married woman by herself and of the society as a whole, as a mom and family care taker, which has not undergone any changes, though she contributes economically to her family.

\section{Women Police: Indian Scenario}

Due to non-availability of appropriate sources, it was difficult to trace the past history of women police. On a trial basis, a police station managed wholly by women had been setup, as because, many women felt comfortable to make a complaint to women rather than to a policemen. In India, few women police were appointed in the year 1938 to deal with labour strikes in Kanpur. Later, few women constables were appointed in 1939 in Bombay and also in Kerala in 1943. 
The former Prime Minister Mrs. Indira Gandhi opened the first police station for women at Calicut in India [10]. In early 90's, Tamil Nadu being a pioneer of women police station and established its first station in Thousand lights, Chennai, under the period of Chief Minister Thiru.M.G.Ramachandran and the first batch came out with the training given byG.Thilagavathi, IPS, first women IPS in Tamil Nadu zone. [8] However, over 28 years later, the vibrant concept of exclusive police station managed totally by women has 'outdated' and 'outlived its utility' [2]The reason is women personnel's are being deployed mostly for "non-sensitive" tasks like temple / festival bandobust or as escort for under- trials and they work in a culture say 24/7.

$D$.

Rationale of the study

It is generally perceived that police professionals face high level of stress and they are trapped between the rising threats of violence and high public demand. It is apparent that in comparison to police professional sizable numbers of police men are committing suicides due to their day to day pressures. Recent report from NCRB has confirmed that 226 police men ended their lives in India. Many such instances happened in case of Tamil Nadu women police. Notably cases like M.Jaihind Devi, Police Inspector(Neyveli, Thermal Power Plant Police Station) committed suicide due to family issues in addition to that there is also another witness of DSP Vishnu Priya (Namakkal) who committed suicide due to the harassment by her superiors. One such strong reason for high suicide rate is due to spillover effect of stress from work life to family life.

\section{REVIEW OF LITERATURE} balance which is dictated by work-family conflict and family-work conflict on the well being of police personnel. The well being was estimated by levels of family and work satisfaction and mental pressure [1]

J. Patricia Jhansi Rani, Dr. D. Joseph Anbarasu in his investigation covered different elements of women police service and its consequences for the family, like authoritative perspectives, work time, monetary status, family management and job related stress. The researcher puts that disappointment among women police can be decreased by improving the nature of work life by giving an appealing arrangement of remunerations and acknowledgment for their work and by improving the workplace. [5]

Nidhi K Yadav has studied satisfaction level with work life balance of women police personnel in Vapi city. The study measured the level of satisfaction perceived by the women police personnel with respect to work life balance and identified the key factors that influence the work life balance among different categories of women employees in police department. It is found that majority of the women employees in police department are dissatisfied and they have some inconsistencies in work life balance. [4]

Dr. Usha Devi $\mathbf{N}$ et al., has analyzed the present scenario in concern with the quality service among women police and its expected progress in the light of work life balance by discussing its challenges. This study limelight the association between work life and excellence in service.[9]

VijayakumarBharathi. S et al., has examined to find out
Dr. OM Ashtankar surveyed the effect of work-life

the challenges in professional and personal life and enhancers of WLB amongst 186 working women in Indian IT sector. The primary difficulties in professional life were broadened working hours, traveling time and partaking in added jobs and assignments. In personal life, the principle stressors were liable cognizance of not having the option to deal with their very own and elder people at home, and a maniac towards social media. The outcomes obtained indicated that most of the women would lean toward flexitime and supportive spouse, family and partners as well as a conducive work environment to carry out her work at office. [11]

Nancy $R$ Lockwood has furnished human resource professional with a chronicled point of view, i.e., information and potential answers for representatives who are similar and organizations to adjust work-life. She puts that three factors in particular worldwide challenges and competitions, individual lives/family values and a maturing workforce present difficulties that makes work/life balance more regrettable. What's more, she offers the perspective that, human asset experts can assist their organizations to exploit on these variables by utilizing work/life activities to increase an aggressive edge in the work place.[3]

ShobhaSundaresan has critically analyzed the elements affecting work-life balance among working women and the outcomes of poor work-life balance. Data was gathered through questionnaire from 125 haphazardly selected working women across over different firms / institutions in Bangalore city. Results indicate that part of working women are encountering trouble in adjusting work and family because of high work requests, investing small energy for themselves and to satisfy others' needs and desires. And furthermore the investigation reveals that that majority of the working women experience a drip over their job into the house as they have to put in longer duration of hours. The findings have inferences for working women and provide deep insights into finding way out to maintain healthy work life balance. [7]

\section{A.}

\section{Research Gap}

The present study is more or less similar to other studies done by various scholars, but still there are certain distinctions that have been lime lighted in this study. The ultimate logical reason behind this research is to improvise the women police personnel's personal life associated with their professional life. Previously much number of studies has been conducted under the concept Work-life balance, but in Indian scenario, particularly in southern region only few studies have been witnessed. And certain studies are concentrated only on some particular region, state or country. Hence, so far much research has not been carried in this area, so it is essential to explore and to get a deep insight in the impact of work - life balance among the women police personnel in Salem city.

\section{NEED FOR THE STUDY}

In recent times, women faces a conflicting situation, i.e., her dual commitment by combining work life with her household activities. 
This situation arose because of the pre-conceived notion that prevails in the society related to women factors. This scenario must be changed, as because woman's status has an important bearing, as they also participate equally in economic activity. And with more additional women working than ever before and rise of dual earner's families, work-life balance has become an ongoing search. Hence, it is necessary to simultaneously examine the working environment of women and under the conditions which she works. Besides, work intensification in police department has made women police personnel to work for longer hours, as a result numerous personnel's are experiencing reduced quality of work-life. This in turn has led to work-life imbalance. This research work is an effort to study the various factors that affect the work and family life of women police personnel.

\section{STATEMENT OF THE PROBLEM}

Policing work offers a sense of security and it is a kind of motivating work for women. But recent research indicates the proportion of women remains below one quarter, with much worse number in higher ranks, which shows that women remain under- represented in many developing countries. One of the main basic sources of stress for women police is their role as women police itself. Occupational physicians and psychiatrists in the Occupational Disease Intelligence Network (ODIN) have reported that amongst the top three occupations, Policing are the most victims of Occupational Stress and mental illness [6]. It is obvious that in police personnel while performing their duty, sizable numbers yield to the daily pressures which make them to come out from the job. This has led to a sequence of problems like role overload, dependent care issues, quality of health, problems in time management and lack of social support. This brings lots of worry and stress among women police personnel. The objective of this study is to address various issues faced by women police personnel and to improve their performance by maintaining a balance between personal life and work life.

\section{OBJECTIVES}

$>\quad$ To measure the present level of awareness on work-life balance among women police personnel in Salem City.

$>\quad$ To observe and analyze the existing pattern (i.e. prevailing routines, schedules) of work-life balance among women police personnel. in work life.

$>\quad$ To study and measure the impact of work-life balance on family.

\section{VI.RESEARCH METHODOLOGY}

Descriptive study is used for this research work. The study relies on both primary and secondary data. The structured questionnaire was distributed to 105 women police. The process resulted in the collection 70 responses complete on all parameters for data analysis and interpretation. The data were collected from women police personnel's from three All women police stations namely Ammapet Women police station, Town Women police station, Suramangalam All women police station and from AR (Armed Reserve) in Salem city andLikertscalewere used to observe the priorities. Secondary data was collected from journals, websites, research articles and from periodicals of police department.Convenience sampling technique has been used to collect the sampleof 70 women police employees in Salem city.

Table I: Distribution of sample

\begin{tabular}{|l|l|l|c|}
\hline S.NO & POLICE STATION & $\begin{array}{l}\text { TOTAL } \\
\text { WOMEN } \\
\text { POLICE }\end{array}$ & $\begin{array}{l}\text { SAMPLE } \\
\text { TAKEN }\end{array}$ \\
\hline 1. & $\begin{array}{l}\text { AWPS 1 - TOWN } \\
\text { POLICE STATION }\end{array}$ & 17 & 09 \\
\hline 2. & $\begin{array}{l}\text { AWPS 2 - AMMAPET } \\
\text { POLICE STATION }\end{array}$ & 15 & 08 \\
\hline 3. & $\begin{array}{l}\text { AWPS - } \\
\text { SURAMANGALAM } \\
\text { POLICE STATION }\end{array}$ & 14 & 08 \\
\hline 4. & AR(ARMED RESERVE) & 200 & 80 \\
\hline \multicolumn{2}{|c|}{ TOTAL246 } & 105 \\
\hline
\end{tabular}

(Source:Duty Roster, 2019)

A. DATA ANALYSIS \& INTERPRETATION Reliability of sample: Cronbach Alpha Value in SPSS is used to check internal consistencies of the set of items give, which is $\alpha=0.571(<0.50)$. Hence, it is inferred that the given data set is quite reliable for analysis.

Table - II

\begin{tabular}{|l|c|}
\hline \multicolumn{2}{|l|}{ Reliability Statistics } \\
\hline $\begin{array}{l}\text { Cronbach's } \\
\text { Alpha }\end{array}$ & N of Items \\
\hline \multicolumn{1}{|c|}{.571} & 27 \\
\hline
\end{tabular}

Table - III: Demographic classifications of Sample Respondents

\begin{tabular}{|c|c|c|c|}
\hline S.N O & PARTICULARS & FREQUENC Y & PERCENTA GE \\
\hline 1. & \multicolumn{3}{|c|}{ AGE(Years): } \\
\hline & $20-30$ & 6 & 8.6 \\
\hline & $30-40$ & 37 & 52.9 \\
\hline & Above 40 & 27 & 38.6 \\
\hline 2. & \multicolumn{3}{|c|}{ EDUCATIONAL QUALIFICATION } \\
\hline & Higher Secondary & 0 & Nil \\
\hline & Graduate & 51 & 72.9 \\
\hline & Post-Graduate & 19 & 27.1 \\
\hline & \begin{tabular}{l|} 
Others \\
\end{tabular} & 0 & Nil \\
\hline 3. & \multicolumn{2}{|c|}{ MARITAL STATUS } & \\
\hline & Married & 35 & 50.0 \\
\hline & Unmarried & 34 & 48.6 \\
\hline & Separated & 1 & 1.4 \\
\hline & Divorced & 0 & Nil \\
\hline 4. & \multicolumn{3}{|c|}{ FAMILY NATURE } \\
\hline & Joint & 46 & 65.7 \\
\hline & Nuclear & 24 & 34.3 \\
\hline 5. & \multicolumn{3}{|c|}{ PATTERN OF STAY } \\
\hline & Single & 0 & Nil \\
\hline & With Family & 70 & 100 \\
\hline
\end{tabular}


Work Life Balance among Women Police in Salem City, Tamil Nadu

\begin{tabular}{|c|c|c|c|}
\hline \multirow[t]{3}{*}{6.} & \multicolumn{3}{|c|}{ NO.OF FAMILY MEMBERS } \\
\hline & \begin{tabular}{|ll}
$\begin{array}{l}\text { Below } \\
\text { members }\end{array}$ & 4 \\
\end{tabular} & 24 & 34.3 \\
\hline & \begin{tabular}{|l|} 
Above \\
members
\end{tabular} & 46 & 65.7 \\
\hline \multirow[t]{4}{*}{7.} & \multicolumn{3}{|l|}{ SALARY } \\
\hline & Below 20,000 & 13 & 18.6 \\
\hline & $\begin{array}{ll}20,000 \\
30,000\end{array}$ & 47 & 67.1 \\
\hline & Above 30,000 & 10 & 14.3 \\
\hline \multirow[t]{4}{*}{8.} & \multicolumn{3}{|l|}{ EXPERIENCE } \\
\hline & $0-2$ years & 0 & Nil \\
\hline & $2-5$ years & 9 & 12.9 \\
\hline & Above 5 years & 61 & 87.1 \\
\hline
\end{tabular}

From the Table III, it is inferred that majority (52.9\%) of respondents belongs to the age group of $30-40.72 .9 \%$ of respondents are graduated, and majority (50\%) of respondents were married. Most (65.7\%) of the respondents live in Joint family and it is also observed that there are more than 4 members present in their family, Majority $(96 \%)$ of respondents are earning an income ranges from $20,000-30,000$ and most of the respondents have an experience of more than 5 years

\section{Table - IV: CHI SQUARE TESTS - Work-life balance \& Demographic variables}

\section{HYPOTHESIS}

$\mathbf{H}_{\mathbf{0}}$ : There is no significant association between work- life balance and demographic variables factors such as Age, Qualification, Marital status, Salary, and Experience

\begin{tabular}{|c|c|c|c|}
\hline Pearson Chi-Square & Value & df & $\begin{array}{c}\text { Sig.(2- } \\
\text { Sided) }\end{array}$ \\
\hline $\begin{array}{c}\text { Age and Work-life } \\
\text { balance }\end{array}$ & .843 & 2 & .656 \\
\hline $\begin{array}{c}\text { Educational } \\
\text { qualification } \\
\text { and Work-life balance }\end{array}$ & 2.249 & 1 & .134 \\
$\begin{array}{c}\text { Marital status and } \\
\text { Work- life balance }\end{array}$ & .305 & 2 & .859 \\
\hline $\begin{array}{c}\text { Salary and Work- } \\
\text { life balance }\end{array}$ & 2.208 & 2 & .332 \\
\hline $\begin{array}{c}\text { Experience and Work- } \\
\text { life balance }\end{array}$ & .002 & 1 & .961 \\
\hline
\end{tabular}

From the table IV, it is found that chi-square values of Demographic variables and work-life balance are greater than the significance level 0.05 . Hence, it is inferred that there is no relationship between Demographic variables and work-life balance

Table - V: One-way Analysis of variance among the Respondent's Age with regard to various Family factors and its impact on Job performance

\begin{tabular}{|c|c|c|c|c|c|}
\hline S.NO & SOURCE & d.f & SS & MS & INFERENCE \\
\hline \multirow{4}{*}{1.} & \multicolumn{5}{|c|}{ Reduces the amount of time you spend with your family } \\
\hline & $\begin{array}{l}\text { Between } \\
\text { groups }\end{array}$ & 2 & .144 & .072 & $\mathrm{~F}=.323$ \\
\hline & \multirow{2}{*}{ Within groups } & \multirow{2}{*}{67} & \multirow{2}{*}{14.941} & \multirow{2}{*}{.224} & $\begin{array}{c}\mathrm{P}=.725(< \\
0.05)\end{array}$ \\
\hline & & & & & Not Significant \\
\hline
\end{tabular}

From table - V, it is understood that there is a significant association between the age of the respondents with respect to two family factors, i.e problems at work make you to irritate at home and your job takes up so much energy where you don't feel up to doing things that need attention at home. Hence, the above table concluded problem at work leads the respondents to act aggravate at home due to the differences in age group.

\section{LIMITATIONS}

This study pertains to certain limitations, as it was conducted for assessing the effects of work-life balance on Police department in Salem city. Hence, the implication of the study is confined to Salem city only; it cannot be generalized for the other areas. The sample size was small and convenience sampling technique was used to collect data which has its own limitations.

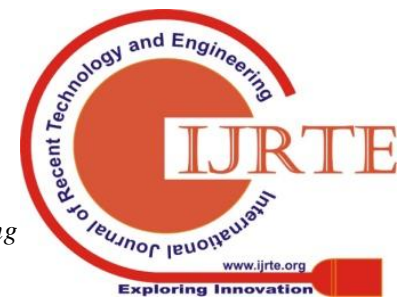




\section{RECOMMENDATIONS BASED ON THE FINDINGS OF THE STUDY}

- $\quad$ Majority of the women police are in the grade of "Head Constables" who are almost in the stage of retirement and they are all working without any promotional opportunities. So, a proper reform has to be implemented in the promotion policy to justify their seniority.

- There are also some police women who are young, energetic and elegant and they are ready to accept all kind of jobs equal to men. By doing so, the dynamism of women police can be maintained rather than placing them in police stations.

- Various Employee Assistance Programmes(EAP's) like awareness training, psychological training programmes, Self-awareness training programmes can be introduced to Police department so that they will enjoy a quality work life. - Changes can be adopted in working hours and with shifts system, so that it can minimize the stress level of women police employees, so this might bring a balance between their work-life.

\section{IX.CONCLUSION}

This research concludes that WLB is essential for women personnel's working in police department. The study inferred that most of the women police personnel's are facing work-family conflict and this in turn will lead to a psychological distress. The women police should be positively motivated by improving quality of work life by providing an attractive reward and recognitions system which will reduce the level of dissatisfaction, they must be properly educated about the environment under which they work. Deployment of women police should be minimized. Prior counseling should be given, so that it would be helpful for the employee's to overcome their stress. In order to meet out their family needs, flexible working options can be provided. Hence, the police department can implement friendly, share and care approaches towards women police, so that it will be easy for them to meet out the work-family challenges.

\section{REFERENCES}

1. Ashtankar, O. (2016). Analysis of the impact of work life balance on wellbeing of police department employees of Nagpur district. International Journal of Applied research, 1-4.

2. Meeran, B. C. (2018, August 28). All Women Station, an outdated concept.

3. Nancy, L. R. (2003). Work/Life Balance: Challenges and Solutions. SHRM, 1-12

4. Nidhi, Y. K. (2015). International Journal of Advanced Research inEngineering, Science \& Management, 1- 3.

5. Patricia, R. J., \& Joseph, A. D. (2016). A Study on Women Police Service and its effects on the Family at Trichy. International Journal of Applied Services Marketing Perspectives@ Pezzottaite Journals. 2-11.

6. Rajpreet, K. (2014). - The Indian Journal of Police

7. Shobha , S. (2014). WORK-LIFE BALANCE - IMPLICATIONS FOR WORKING WOMEN. International Journal of Sustainable Development, 1-11.

8 Soma, B. (2017, June). Retrieved from www.thehindu.com.
9. UshaDevi , N., Preema, D., \& Swathi , N. (2018). Work life balance: A tool for quality service. International Journal of Commerce \& Management, 1-13.

10. Ushadevi, D sa, P., \& Swathi, N. (2018, January). Worklife balance: A tool forquality service. JIGNASA International Journal of Commerce \& Management, 50- 62.

11. Vijayakumar, B. S., Padma, M. E., \& Sonali , B. (2015). Work life balance of women employees in the information technology. ASIAN JOURNAL OF MANAGEMENT RESEARCH, 1-21.

\section{AUTHORS PROFILE}

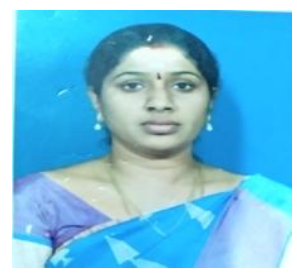

D. Bhuvaneswari, has completed her Bachelor of Computer Application in the year 2011 affiliated to Periyar University, Salem. She then completed her Post Graduation and received her Master degree in Business Administration at K.S.R 'B' School, Anna university in the year 2011.During Post Graduation her specialization was HR and Finance. She has been working in Jairam Arts \& Science college, and has five years of teaching experience, and simultaneously, then she continued her education at Vinayaka Missions University pursuing M.Phil in Management. She submitted her dissertation in the area of Emotional Intelligence among employees working AAVIN. She got cleared in State Level Eligibility test (SET) in the year 2018 and UGC NET in the year 2019. She has also been as a SWAYAM co-ordinator while working in Jairam Arts \& Science college. Papers presented four at National level and 3 at International level. Currently she is pursuing her Full-Time Doctoral degree in Management Studies at Periyar University.

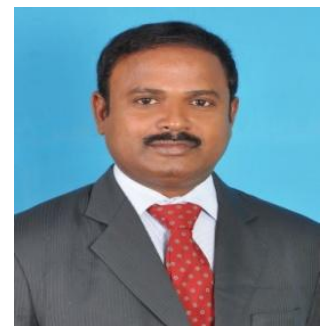

Dr. P. Thirumoorthi, has completed his Mechanical Engineering in PSG college of Technology in the year 1991. He then completed his MBA programme in Bharathiar School of Management, affiliated to Bharathiar University in 1993. He pursued his Doctorate in management in the year 2010 at Periyar University, Salem. He has a corporate experience for four years 8 months, later in the year 2005 he switched his career as a lecturer in Kongu Engineering College, Erode. In 2005, he joined at Periyar University, as Assistant professor to till date. He's also been promoted as Associate professor. Apart from academic, he has also served as Duty director (i/c), Periyar Institute of Distance Education for more than one year, Periyar University. He has eight years of experience in Youth Red Cross, Periyar University and more than one year of experience as Public Relation Officer in Periyar University. Currently, he is serving as a convener, in Career \& Counselling / Placement cell, Periyar University. He has an award for his meritorious service towards Academic Excellence 2003 - 04, by Kongu Engineering College. And he has also been awarded as Best Zonal Co-Ordinator of Youth Red Cross (2010-2011), by Indian Red Cross Society, Tamil Nadu Branch. He has won Second position in 6th International Conference on "Innovative Ways of Managing Business in the Post Globalised Era" held on February 2nd - 3rd, 2013 at Bharati Vidyapeeth Deemed University, Institute of Management and Research, New Delhi. And in addition he has also won 2 best paper awards in Interntioonal conference held at Coimbatore region. He has written and published two books. He has published 33 paper in Referred Journal, 36 ISBN publications, and he has organized 8 workshops, and attended 12 workshops. He has organized one International conference and worked as a committee member in 4 International Conferences at Periyar Institute of Management Studies, Periyar University. He has attended 10 International conferences, and 4 National conferences. And he has attended 8 Refresher course, 6 Faculty Development programmes. Till now, he has guided for 10 $\mathrm{Ph} . \mathrm{D}$ and 25 M.Phil scholars. He has submitted 5 funded projects, notably for UGC, New Delhi and Indian Institute of Public Administration, New Delhi. $\mathrm{He}$ is a member of Member, All India Management Association(AIMA), Member, Indian Society for Technical Education(ISTE), Member, Coimbatore Management Association(CMA), Member, Indian Red Cross Society. 